\title{
Vitamin D ve Antikanserojenik Etkileri
}

\author{
Vitamin D and Its Anticarcinogenic Effects
}

\author{
Murat ARI ${ }^{1}$ (0) \\ ${ }^{1}$ AydınAdnan Menderes Üniversitesi Sağılk Bilimleri Enstitüsü Biyokimya (Tıp) AD, Aydın, Türkiye
}

ÖZ

\begin{abstract}
Vitamin D, yağda ve organik çözücülerde çözünen, fakat suda çözünmeyen, sahip olduğu reseptörleri aracılığılla her organ ve dokuya ulaşı önemli görevler yapması sebebiyle hormon benzeri görev yapan bir grup sterol olarak ifade edilir. Kalsiyum ve fosfor metabolizmasının devamlılı̆ııın sağlanmasında majör rol oynar. Yapılan pek çok çalışmada, D vitamininin aktif formu olan $1,25-\mathrm{OH}_{2} \mathrm{D}_{3}$ 'ün aynı zamanda hücre proliferasyonu, apoptotik ve antioksidan etkilerinin de olduğu ortaya çıkarılmıştır. $\mathrm{Bu}$ derlemenin amacı, vitamin $\mathrm{D}$ ve metabolitlerinin herkes tarafindan bilinen majör rolünün yanı sıra kanser ve buna bağı olarak otoimmun hastalıklar, bağışıklık sistemi ile ilgili ilişkilerini vurgulamaktır.
\end{abstract}

Anahtar Kelimeler: Vitamin D, Antioksidanlar, Kanser.

ABSTRACT

Vitamin D is identified as a hormon-like group of sterols, dissolved in oil and organic solvents, but do not dissolve in water act as hormones, because it reaches every organ and tissue through their receptors and perform important tasks. It plays a fundamental role in maintaining calcium and phosphorus metabolism. Many studies have revealed that the active form of vitamin $\mathrm{D}\left(1,25-(\mathrm{OH})_{2} \mathrm{D}_{3}\right)$ has also cell proliferation, apoptotic and antioxidant effects. The purpose of this review is to highlight the major role of vitamin D and its metabolites, as well as cancer and their relation to autoimmune diseases, immune system.

Key Words: Vitamin D, Antioxidants, Cancer.

\section{GİRIŞ}

Vitamin D, en genel ifadeyle yağda ve organik çözücülerde çözünen, fakat suda çözünmeyen bir grup sterol olarak tanımlanmaktadır (1). Günümüze kadar hormon olarak mı, yoksa vitamin olarak mı değerlendirilmesine dair tartışmalar süregelmekteydi. Fakat sahip olduğu reseptörleri aracılığıyla her organ ve dokuya ulaşıp önemli görevler üstlenmesi sebebiyle araştırıcılar tarafından prohormon olarak tanımlanmaktadır (2). Vücutta meydana gelen çeşitli metabolik değişikliklerle vitamin D'nin aktif formu olan kalsitriola dönüşür. Kalsitriol, kalsiyum ve fosfor metabolizmasında önemli rol oynayan bir hormondur. Vitamin D’nin majör görevi, kalsiyum homeostazında önemli görev yapmasıdır. Serum ve vücut sıvılarında kalsiyum miktarını artmasını sağlayıp, buna bağlı olarak kemik büyümesine yardımc1 olur. Kalsiyum metabolizmasında rol alan diğer hormonlar, parathormon ve kalsitonindir (3). Vitamin D, sadece omurgalılar için esansiyeldir. Vitamin D'nin bazı bitkilerde ve ışına maruz bırakılmış mayalarda bulunan $\mathrm{D}_{2}$ formu (ergokalsiferol) ve hayvanlarda ve balık yağında doğal olarak bulunan $\mathrm{D}_{3}$ formu (kolekalsiferol) olmak üzere 2 çeşit formu 
bulunmaktadır. Her iki form da hem diyetle alınabilir, hem de sentetik olarak üretilebilir $(4,5)$. $\mathrm{Bu}$ iki form normalde inaktiftir. Karaciğer ve böbrekte meydana gelen iki adet hidroksilasyon basamağıyla aktive edilir. Vitamin D'nin aktif formu olan 1,25 dihidroksikolekalsiferol (kalsitriol) aracılığıyla hedef organları böbrekler, ince bağırsaklar ve kemikler aracılığıyla vücudumuzda serum kalsiyum ve fosfor düzeyleri düzenlenir (6). Bu derlemede vitamin D'nin temel fonksiyonlarının yanı sıra özellikle hücre proliferasyonu inhibe etmesi ve apoptozu indüklemesi gibi pek çok antikanserojen etkileri vurgulanmak istenmiştir.

\section{Parathormon ve Kalsitoninin Kalsiyum Metabolizmasındaki Rolleri}

\section{Parathormon (PTH)}

Parathormon, paratiroid bezinden salgılanan bir hormondur. Direkt etkisini, düşük kalsiyum düzeyi ile (hipokalsemi) sentezi uyarılıp bu şekilde plazma kalsiyum düzeylerini arttırarak gerçekleştirir. Yüksek kalsiyum düzeyi ile de (hiperkalsemi) inhibe olur. İndirekt etkisini ise, böbreklerde bulunan 1- $\alpha$-hidroksilaz enziminin aktivasyonu ile D vitaminin inaktif formu olan $25-\mathrm{OH}_{2}-\mathrm{D}_{3}$ 'ü, aktif formu olan $1,25(\mathrm{OH})_{2} \mathrm{D}_{3}$ 'e dönüştürerek bağırsaklardan kalsiyum geri emilimini arttırır, bu sayede plazmda serum kalsiyum dengesi korunmuş olur $(7,8)$

\section{Kalsitonin}

Tiroid bezinden salgılanan, plazmada kalsiyum değeri artış gösterdiğinde (hiperkalsemi) stimüle olan, azaldığında ise redükte olan bir hormondur. Bu yüzden PTH ve kalsitoninin kemik üzerine etkileri birbirlerinin anatagonistiği şeklindedir. Fakat sadece fosforun renal tubuler reabsorbsiyonun azaltılması görevinde aynı yönde etki göstermektedirler (9).

\section{Vitamin D Metabolizması}

$\mathrm{D}_{2}$ ve $\mathrm{D}_{3}$ vitamini normalde inaktiftir. Bunların aktif görev yapabilmeleri için karaciğer ve böbreklerde meydana gelen birtakım enzimatik reaksiyonlarla hidroksilasyona uğraması gerekir. Kolekalsiferolün ilk hidroksilasyon basamağı, karaciğerde kolekalsiferol-25hidroksilaz enzimi aracılığıyla 25. karbondan başlar. Bu hidroksilasyon sonucunda 25hidroksikolekalsiferol oluşur. Esas aktivasyon basamağı olan ikinci hidroksilasyon basamağ 1 ise böbreklerde gerçekleşir. 25-hidroksikolekalsiferol, 1,25-dihidroksikolekalsiferol enzimi tarafindan katalizlenir ve bu ikinci hidroksilasyon sonucunda 1,25-dihidroksikolekalsiferol oluşur. 1,25-dihidroksikolekalsiferol, D vitamininin en aktif formudur ve bütün etkilerinden sorumludur. Ancak bu formun yarılanma ömrü 15 saat civarı olduğu için, yarılanma ömrü 10 gün civarı olan 25-hidroksikolekalsiferol, daha çok depo formu gibi düşünülebilir (4). Vitamin D metabolizması şekil.1'de gösterilmiştir (10).

\section{Vitamin D Eksikliği}

D vitamini doğada çok geniş bir yayılım göstermez. Direkt olarak güneş 1şınlarından ya da besinlerden alınabilir ya da D vitamini ihtiva eden maddeler, ultraviyole 1şı̆̆a maruz bırakılarak D vitamini içeriği bakımından zengin hale getirilir. Güneş ışınlarından yeterli 


\section{7-dehidrokolesterol

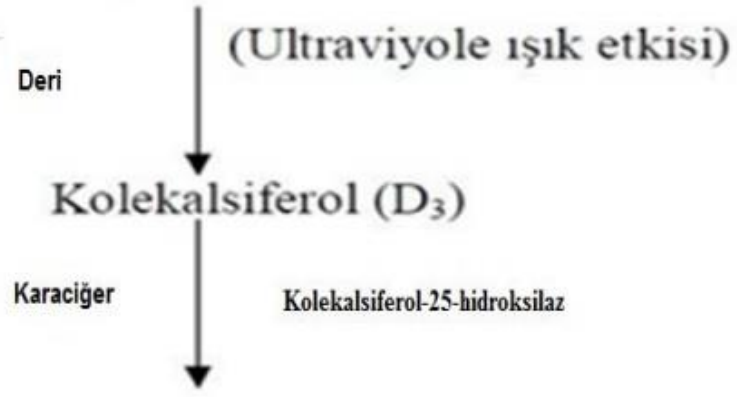

\section{5- Hidroksikolekalsiferol}

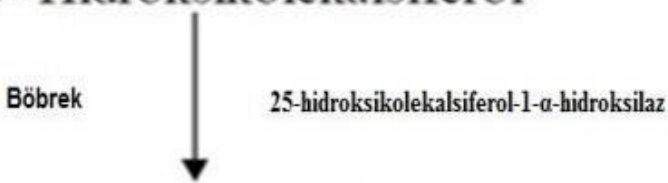

\section{1,25-Dihidroksikolekalsiferol}

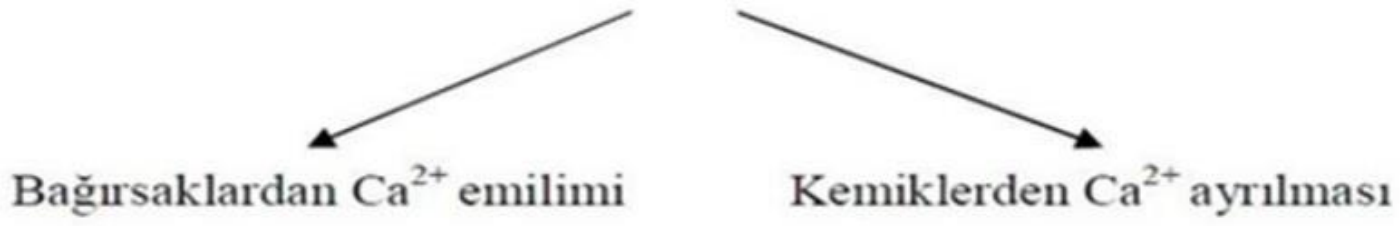

Şekil 1. Vitamin D Metabolizması (10)

miktarda faydalanamamak, D vitamininin yetersizliğinin başlıca sebeplerindendir. D vitamini eksikliğinde, kalsiyum emilim eksikliğine bağlı çocuklarda riketse, yetişkinlerde raşitizme, osteomalaziye ve osteoporoza sebep olabilmektedir. Gen ekspresyonu bozukluğuna bağl1 olarak kanser, diyabet, multipl skleröz hastalıklar başta olmak üzere pek çok hastalığa sebep olabilmektedir. D vitamini eksikliğinde görülebilecek hastalık ve mekanizmaları şekil.2'de gösterilmiştir (11).

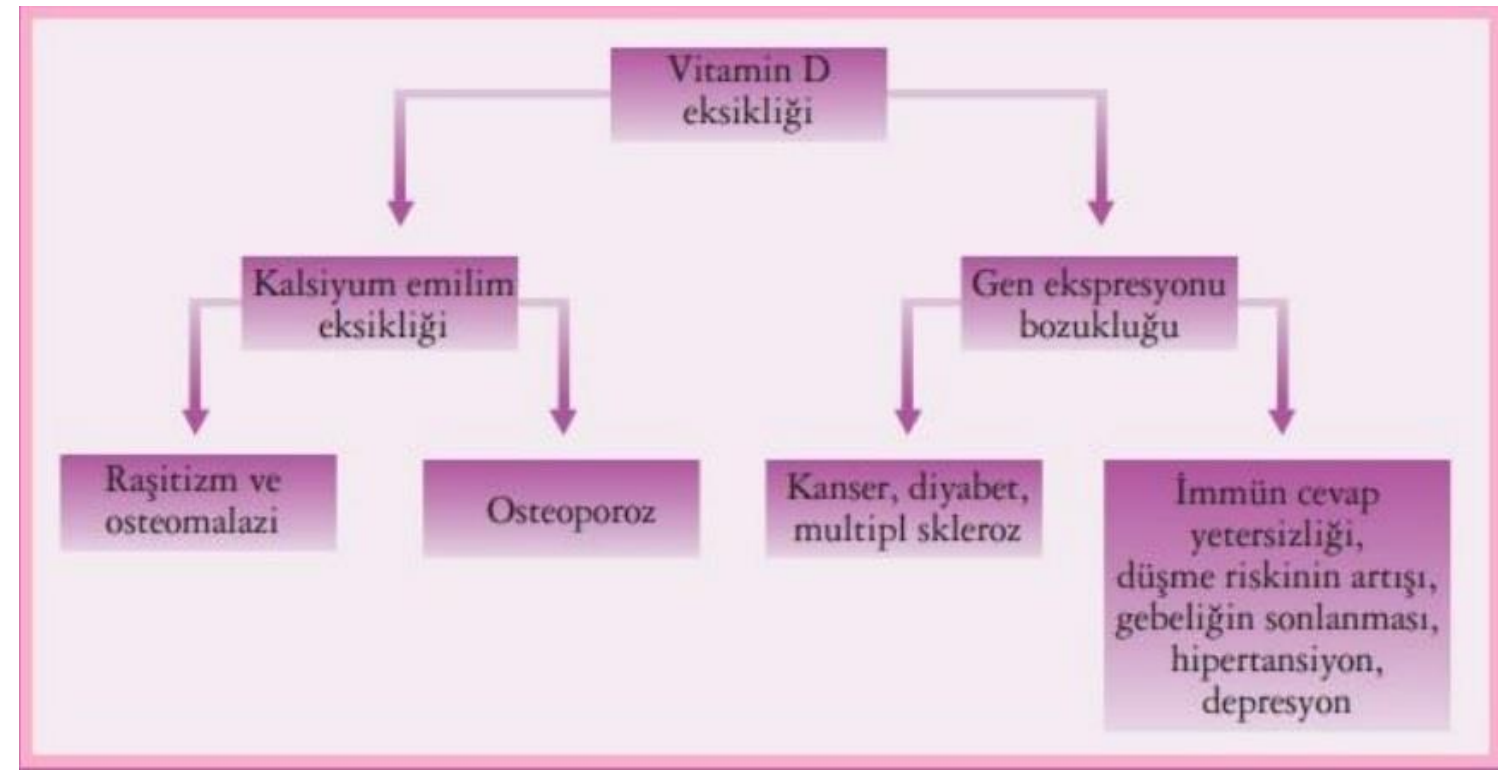

Şekil 2. Vitamin D Eksikliğinde Görülebilecek Hastalıklar (11). 


\section{Vitamin D'nin Antikanserojenik Etkileri}

D vitamini doğuştan gelen bağışıklığın düzenlenmesinde önemli bir rol oynayan bir steroid hormon olarak ifade edilmiştir. Özellikle immun sistem üzerinde etkisi görüldüğü için başta kanser olmak üzere pek çok hastalık üzerinde koruyucu ve hatta tedavi edici etkisi görülmektedir (12,13). Vitamin D hem doğal, hem de kazanılmış bağışıklıkta etkin rol oynar. Vitamin D ve aktif metabolitlerinin bağışıklık sisteminin düzenlenmesinde etkileri ilk olarak 30 yıl önce kadar yapılan çalışmalarda ifade edilmiştir. Bunlar: insanlarda aktif olan inflamatuar hücrelerde vitamin $\mathrm{D}$ reseptörünün (VDR) olması, aktif $\mathrm{D}$ vitamininin $\mathrm{T}$ hücre proliferasyonunu inhibe etme özelliği, akciğerlerde granulom oluşmasıyla oluşan tüberküloz ve sarkoidoz gibi hastalıklarda aktif hale gelen makrofajların 1- $\alpha$ hidroksilaz ekspresyonu ile aktif D vitaminini üretebilmesidir (14). Yapılan pek çok klinik, epidemiyolojik, in vitro hücre kültürü, in vivo hayvan çalışmalarında vitamin D ve analoglarının sadece bilinen kalsiyum metabolizmasının devamlılığını sağlamakla kalmadığı, aynı zamanda kalsemik olmayan antiproliferatif, apoptotik ve antioksidan etkileri sayesinde kanserin tedavisinde ve kansere karşı korunmada etkili olduğu da gözlemlenmiştir $(15,16)$. D vitamininin vücudun sağlığının korunmasında ve buna paralel olarak pek çok hastalığın gelişimini inhibe ettiği bilinmektedir. Vitamin D'nin majör formu olan 25-hidroksikolekalsiferol formunu, aktif formu olan kalsitriola çeviren 1- $\alpha$-hidroksilaz enziminin immun sistem üzerinde etkilerinin görülmesi, vitamin D'nin biyolojik etkilerinin daha geniş bir yelpazede olduğunu ve bir antioksidan gibi etki gösterdiğinin kanıtıdır (17-19).

Vitamin D ve kanser ilişkisi ilk defa 1941 yılında yapılan bir çalışmayla ortaya çıkarılmıştır (20). Özellikle meme ve kolon kanseri ilişkisi dikkat çekmektedir. İn vitro hücre kültürü ve in vivo hayvan çalışmalarında vitamin D'nin aktif formu olan kalsitriolün hücre diferensiasyonunu arttırdığ proapoptototik ve antianjiyogenik etkilerinin olduğu gösterilmiştir. Özellikle in vitro hücre kültürü çalışmalarında kalsitriolün VDR'ye bağlanarak hücre proliferasyonunu inhibe eden çeşitli genleri regüle ederek kanserli hücrelerin büyümesini inhibe ettiği gözlemlenmiştir $(21,22)$ Kalsitriol, hücre döngüsünde yer alan p21 ve p27 ekspresyonunu uyarır, hücre adezyon molekülü olan e-kaderin ekspresyonunu uyararak DNA hasarının tamirini ve p53 miktarını arttırdığı gösterilmiştir (14). Buras ve arkadaşlarının 1994 yılında yaptıkları çalışmada, 10, 100 ve $1000 \mathrm{nM}$ konsantrasyon vitamin D'nin meme kanseri hücre hattının (MCF-7) büyümesini anlamlı inhibe ettiğini gözlemlemişlerdir (23). Brenner ve arkadaşlarının 1994 yılında Buras ve arkadaşlarının yaptıkları çalışmayı referans alarak 1995 yılında yaptıkları çalışmada, verdikleri dozun 6. gününde, $10 \mathrm{nM}$ konsantrasyonda vitamin D'nin MCF-7 hücre hatlarının büyümesini anlamlı bir şekilde inhibe ettiğini gözlemlemişlerdir (24). 1996 yılında Campbell ve arkadaşlarının MCF-7 hücre hattı üzerinde vitamin D'nin antiproliferatif özelliğine baktıklarında, $100 \mathrm{nM}$ konsantrasyonda vitamin D'nin 48. saatte MCF-7 hücre hattının büyümesini anlamlı inhibe ettiğini gözlemlemişlerdir. $100 \mathrm{nM}$ konsantrasyon vitamin D'nin apoptozu da indüklediği gözlemlenmiştir (25). Saraçlıgil ve arkadaşlarının 2017 yılında yaptıkları çalışmada D vitamininin MCF-7 hücre hattı üzerinde etkisi incelendiğinde, 48. saatte IC $_{50}$ değeri $145 \mathrm{nM}$ olarak bulunmuştur (26). Murray ve arkadaşlarının 2017 yılında yaptıkları çalışmada ise $\mathrm{IC}_{50}$ değeri $1.83 \pm 0,69 \mu \mathrm{M}$ olarak bulunmuştur (27). 2018 yılında Arı ve arkadaşlarının yaptıkları çalışmada ise $\mathrm{IC}_{50}$ değeri 48 . saatte $2,053 \mu \mathrm{M}$ olarak bulunmuştur (28). 
Aynı zamanda yapılan bazı çalışmalarda vitamin D'nin pek çok kemoterapötik ajanla da kombinasyon şeklinde kullanılmış ve daha güçlü sinerjetik etki gösterdiği anlaşılmıştır. Segovia-Mendez ve arkadaşlarının 2015 yılında yaptıkları çalışmada kalsitriol ve gefinitibin MCF-7 üzerine birlikte etkisini incelemişler ve kalsitriol-gefinitibin kombinasyonunun MCF-7 hücre hattı üzerinde güçlü sinerjetik etkiye sahip olduğunu gözlemlemişlerdir (29). Ar1 ve arkadaşlarının (2018) yaptıkları çalışmada oleuropein ve vitamin D'nin MCF-7 meme kanseri hücre hattı üzerinde sinerjetik etkisi olduğu gözlemlenmiştir (28). Tüm bu çalışmalar, vitamin D’nin kanser hücrelerine karşı başka kemoterapötik ajanlarla beraber kullanıldıklarında daha etkili olabileceğini göstermiştir (28).

Vitamin D'nin aktif formu olan kalsitriolün ve analoglarının insan kolon kanseri hücresinde de proliferasyon ve diferansiyasyonu inhibe ettiği gözlemlenmiştir (30). Zgaga ve arkadaşlarının 2014 yılında yaptıkları çalışmada, vitamin D'nin majör formu olan 25-(OH $)_{2}$ $\mathrm{D}_{3}$ 'ün yüksek plazma seviyelerinde, VDR genine bağlı olarak kolorektal kanser sağkalımında daha etkili olduğu gözlemlenmiştir (31). Spina'nın 2005 yılında yaptığı in vivo çalışmada, yeterli ve düzenli D vitamini almış farelerde kolon kanseri büyümesinin anlamlı derecede inibe olduğu gözlemlenmiştir (32). Leyssens ve arkadaşlarının 2015 yılında yaptıkları çalışmada, Caco-2, SW1417 ve SW480-ADH kolon kanseri hücre hatlarında, vitamin D'nin aktif formu olan $1,25(\mathrm{OH})_{2} \mathrm{D}_{3}$ 'ün belirli konsantrasyonlarda hücre proliferasyonunu azalttı̆g 1 gözlemlenmiştir (33,34). Tangpricha ve arkadaşlarının 2005 yılında yaptıkları çalışmada önceden belirlenmiş, plazma seviyelerinde yeterli ve yeterli olmayan vitamin D bulunan farelere, kolon kanseri hücreleri enjekte edilmiş ve D vitamini eksikliği olan farelerde kolon kanseri tümörünün büyümesinin anlamlı olarak daha fazla olduğu gözlemlenmiştir (35). Aynı zamanda prostat kanseri hücrelerinde VDR ekspresyonu gösterilmiştir. Yapılan in vitro çalışmalarda kalsitriolün antiproliferatif ve profiferansiyatif etkiler göstererek prostat kanserini inhibe ettiği gözlemlenmiştir (36).

D vitamininin kanserdeki etkisi, büyük ölçüde epidemiyolojik gözlemlerle desteklenmiştir. Pek çok epidemiyolojik çalışma, güneş 1şığının prostat, kolon, rektal, meme ve yumurtalık kanserine karşı koruyucu etkisi olduğunu göstermektedir. Coğrafi olarak güneş ışığının arttığı yerlerde kanser insidansı, özellikle meme ve kolon kanseri için için daha düşüktür (37). Araştırmacılar, kanda dolaşan D vitamininin kolorektal ve prostat kanserine karş1 koruyucu etkisi olduğuna göstermişlerdir (38). Yapılan çalışmalar, üçlü negatif meme kanseri hastalarının \%87'si yetersiz serum $25(\mathrm{OH})_{2} \mathrm{D}_{3}$ seviyelerinden kaynaklanmaktadır (39). İki ayrı retrospektif çalışmada kontrol grubuyla kıyaslandığında prostat kanseri gelişen hastaların vitamin D düzeylerinin daha düşük olduğu gözlemlenmiştir (40). Benzer şekilde, düzenli olarak D vitamini alan kadınlarda, almayanlara göre kolorektal kanser riskinin \%67 daha düşük olduğu gözlemlenmiştir $(38,41)$.

Ancak randomize kontrollü çalışmalarda D vitamini ve analoglarının kanser insidansı ve mortalite üzerine anlamlı etkisi tam olarak gösterilememiştir $(14,18)$. Trivedi ve arkadaşlarının 2003 yılında yaptıkları çalışmada 65-85 yaş aralığındaki 2686 erkek ve kadından oluşan gruba 4 ayda bir 100.000 IU vitamin $\mathrm{D}_{3}$ replasmanı yapılmış ve 5 yıllık takip yapılmıştır. 5 yılın sonunda plasebo ile kıyaslandığında kanser insidansında anlamlı bir farklılık gözlemlenmemiştir (42). Yine randomize kontrollü yapılan başka bir çalışmada hastalara günlük $1000 \mathrm{mg}$ Ca ve $400 \mathrm{IU}$ vitamin $\mathrm{D}_{3}$ verilmiş, 7 yıllık bir takip yapılmıştır. 7 yılın sonunda plasebo ile kıyaslandığında meme kanseri insidansı ve mortalitesinde anlamlı bir farklılık 
gözlemlenmemiştir (43). Büyük ölçekli bir kohort çalışmada mide, böbrek, pankreas, endometrium, özefagus gibi nadir görülen kanserler ile $25(\mathrm{OH})_{2} \mathrm{D}_{3}$ arasında anlamlı bir ilişki görülmemiştir (44).

Sonuç olarak, hücre kültürü in vitro çalışmalarda, kanser ile aktif vitamin D arasında anlamlı korelasyon gözlemlenmiştir. $\mathrm{Bu}$ çalışmalar epidemiyolojik çalışmalarla da desteklenmiştir. İn vivo hayvan çalışmalarında bu ilişki daha zayıf olarak saptanmıştır. Randomize kontrollü çalışmalarda ise anlamlı bir ilişki gösterilememiştir ve bu çalışmalar daha az sayıdadır. D vitamini ve kanser ilişkisini gösterecek daha fazla randomize kontrollü çalışmaya ihtiyaç vardır (45).

Başta meme ve kolon kanseri olmak üzere prostat, akciğer, deri, mesane, prostat, yumurtalık kanseri lösemide kanser hücre proliferasyonunu inhibe edici özelliği olduğunu gösteren pek çok hücre kültürü çalışması mevcuttur. Vitamin D'nin aktif formu olan kalsitriolün antikanser etkisinin mekanizması tablo. 1'de özetlenmiştir $(46,47)$.

Tablo 1. Kalsitriolün Antikanserojenik Mekanizması $(46,47)$

\begin{tabular}{ll}
\hline Proliferasyon etkisi & P21 VE P27 ekspresyon artışı \\
& CDKs, siklinler, MYC ve RB ekspresyonunun azalışı \\
\hline Apoptotik etkisi & BAX artışı \\
& BCL-2 azalışı \\
& Radyasyon ve kemoterapi duyarlılı̆̆ının artışı \\
\hline Diferansiyasyon etkisi & Miyeloid lösemi hücrelerinin monositlere ayrılması \\
& Kazein, lipitler, PSA, E-cadherin gibi diferansiyasyon \\
& faktörlerinin ekspresyonunun artışı \\
\hline İnflamasyon etkisi & COX2, PG reseptörleri, stres kinaz ve NF- Kb sinyal \\
& yolaklarının ekspresyonunun inhibisyonu \\
\hline İnvazyon ve metastaz etkisi & MMP9, $\alpha 6$ integrin, plasminojen aktivatör \\
& ekspresyonunun inhibisyonu \\
\hline Anjiyogenez etkisi & H1F1 $\alpha$, VEGF, IL-8, tenasin C, PGE2 S \\
& seviyelerinin azalış1 \\
\hline
\end{tabular}

\section{Vitamin D Toksisitesi}

Vitamin D'nin eksikliğinde görülebilecek eksikliklerin yanı sıra vücuda fazla alınmasında ya da yanlış kullanımlar sonucu vitamin D intoksikasyonu da görülebilmektedir (48). Pek çok hastalığın önlenmesi veya tedavisi için olumlu olabilecek etkilerinden dolayı D vitamini kullanımı günümüzde ciddi bir popülarite kazanmıştır. Bu yüzden hekim önerisi olmadan kullanımların arttığı gözlemlenmiştir. $\mathrm{Bu}$ açıdan bakıldığında, vitamin $\mathrm{D}$ takviyelerinin hekim önerisi ile uygun dozda kullanılması konusunda toplumun bilgilendirilmesi önem teşkil eder. Hekim açısından bakıldığında da, hekimlerin gerekli laboratuvar bulguları olmadan hastalara yüksek doz vitamin D vermemeleri gerekir. Ayrıca ailelerin çocuklarının daha çabuk yürümesi veya diş çıkarması için yüksek doz vitamin D kullanımlarıyla ilgili hekimlerin aileleri bilgilendirmesi gerekmektedir (49). D vitamini intoksikasyonunun temel bulguları arasında sindirim kanalından fazla kalsiyum emilimi sonucu ortaya çıkan hiperkalsemi gelişimidir. Bunun yanı sıra hiperkalsiüri, hiperfosfatemi ve uzun dönem aralığında yumuşak doku, vasküler kalsifikasyonlar, nefrolitiyazise de sebep olabilmektedir (48). Fazla kalsiyum alımı, sindirim sistemi, sinir, kalp, kas ve böbrekleri etkiler ve buna bağlı olarak, yorgunluk, kaslarda ileri derecede güçsüzlük, hipotoni, karın ağrısı, bulantı, kusma, kabızlık, dehidratasyon, poliüri, peptik ülser, koma, bilinç bulanıklı̆̆ı, böbrek 
yetmezliği, hipertansiyon gibi bulgular gelişebilmektedir. Bu sebeple, vitamin D alımının pek çok hastalığa karşı etkili olmasına rağmen, gereğinden fazla alımına son derece dikkat edilmesi gerekmektedir (50).

Vitamin D düzeyi $30 \mathrm{ng} / \mathrm{ml}$ 'nin $(75 \mathrm{nmol} / \mathrm{L})$ üzerinde ise yeterli, $20-30 \mathrm{ng} / \mathrm{ml}(50-75$ $\mathrm{nmol} / \mathrm{L})$ aralığında ise yetersizlik, $20 \mathrm{ng} / \mathrm{ml}$ 'nin ( $50 \mathrm{nmol} / \mathrm{L})$ altında ise eksiklik olarak kabul görmektedir (51). Eğer $150 \mathrm{ng} / \mathrm{ml}$ 'nin üzerinde olduğu durumlarda ise vitamin D intoksikasyonu olarak ifade edilmektedir (52). Perez-Barrios ve arkadaşlarının 2016 yılında yaptıkları çalışmada D vitamininin önemi vurgulanmış, fakat yanlış kullanımına bağlı intoksikasyon etkilerinin özellikle yaşlılarda daha fazla görüldüğü belirlenmiştir (53). Sarı ve arkadaşlarının 2014 yılında yaptıkları çalışmada yüksek doz vitamin D verilen 5 aylık kız çocuğunda hiperkalsemi gelişimini gözlemlemişlerdir (49). Aydın ve arkadaşlarının 2018 yılında yaptıkları çalışmada 75 yaşındaki bir kadın hastanın D vitaminini yanlış kullanması sonucunda akut mental tablosunda değişikler gözlemlenmiştir (54). Bu açıdan bakıldığında yüksek doz D vitamininin vücut içerisinde ağır ve dirençli hiperkalsemi oluşturarak önemli morbidite ve hatta mortalite nedeni olabileceğini göz önünde bulundurarak, özellikle sağlık çalışanlarının, aileleri bu konuda bilgilendirmesi, gereksiz vitamin kullanımının her zaman sağlıklı olmayabileceği, hatta yüksek doz D vitamininin yarar yerine zarar verebileceği vurgulanmalıdır (55). D vitamini intoksiyakosyonundan dolayı oluşan hiperkalsemiye bağlı gelişen semptomlar ve bulgular tablo. 2'de gösterilmiştir $(56,57)$.

Tablo 2. Vitamin D İntoksikasyonu Sonucu Oluşan Semptomlar ve Bulgular $(56,57)$

\begin{tabular}{|c|c|}
\hline Gastrointestinal & $\begin{array}{l}\text { Mide bulantısı ve kusma } \\
\text { Anoreksi, karın ağrısı } \\
\text { Kabızlık } \\
\text { Büyüme geriliği } \\
\text { Pankreatit, peptik ülser }\end{array}$ \\
\hline Böbrekler & $\begin{array}{l}\text { Polidipsi, poliüri, dehidratasyon ve ateş } \\
\text { Hematüri, hipernatremi, hipomagnezemi, } \\
\text { hipokalemi } \\
\text { Nefrolitiyazis, nefrokalsinoz, distal renal tübüler } \\
\text { asidoz } \\
\text { Akut ve kronik böbrek yetmezliği }\end{array}$ \\
\hline Merkezi Sinir Sistemi & $\begin{array}{l}\text { Hipotoni, parestezi } \\
\text { Derin tendon reflekslerinde azalma, baş ağrısı } \\
\text { Mesiyal temporal skleroz } \\
\text { Psikiyatrik bozukluklar (anksiyete, psikoz, } \\
\text { halüsinasyon, depresyon) }\end{array}$ \\
\hline Kardiyovasküler & Aritmi, bradikardi \\
\hline Kas-İskelet Sistemi & $\begin{array}{l}\text { Hipertansiyon, kardiyomiyopati } \\
\text { Kas zayıflığ1 } \\
\text { Kemik ağrıs1 } \\
\text { Osteopeni/ osteoporoz } \\
\text { Osteopetroz }\end{array}$ \\
\hline Gözler & Konjonktival kalsifikasyon \\
\hline Deri & Metastatik kalsifikasyon \\
\hline
\end{tabular}

\section{SONUÇ}

Günümüzde özellikle in vitro deneysel olarak yapılan pek çok çalışmada vitamin D'nin artık antikanser etkilerinin olduğu açıkça ifade edilmiştir. Gereğinden fazla vitamin D alımının toksik etki yapabileceği göz önünde bulundurulursa, hiperkalsemik etkilerinin ortaya çıkmadı̆̆ 
dozlarda diyetle alınan vitamin $\mathrm{D}$, kanser tedavilerinde tekli ya da başka bir ajan ile kombine şekilde kullanılabileceği görüşü bilim dünyasına umut vermektedir. Ancak günümüzde hangi hastaya, ne gibi risk faktörleri göz önünde bulundurularak, hangi dozda, ne sıklıkla verileceği ile ilgili bir guideline henüz bulunmamaktadır. İn vitro çalışmalarda kanser ile aktif vitamin D ilişkisi gösterilmesine rağmen, randomize kontrollü çalışmalarda bu ilişki zayıf ya da gösterilememiştir. Bu sebeple gelecekte vitamin $\mathrm{D}$ ve kanser ilişkisini gösterecek özellikle randomize kontrollü çalışmalara ihtiyaç vardır.

\section{Çıkar Çatışması}

Yazarlar arasında çıkar çatışması yoktur.

\section{KAYNAKLAR}

1. Hochberg, Z. (2004). Requirements for vitamin D in an indoors culture. Highlights, 12, 19-23.

2. Rusinska, A., Pludowski, P., Walczak, M., Borszewska-Kornacka, M., Bossowski, A., \& Chalebna-Sokol, D. (2018). Vitamin D supplementation guidelines for general population and groups at risk of vitamin D deficiency in Poland-Recomendations of the Polish society of pediatric endocrinology and diabetes and the expert panel with the participation of the national specialist consultans and representatives of scientific societies-2018 update. Frontiers in Endocrinology, 9, 246.

3. Dittmer, K. E., \& Thompson, K. G. (2011). Vitamin D metabolism and rickets in domestic animals: A review. Veterinary Pathology, 48(2), 389-407.

4. Montgomery, R., Conway, T. W., Spector, A.A. (2000). Biyokimya olgu sunumlu yaklaşım. Ankara: Palme Yayıncılık.

5. Holick, M. F. (2007). Vitamin D deficiency. N Engl J Med, 357(3), 266-81.

6. Gow, A. G., Else, R., Evans, H., Berry, J. L., Herrtage M. E., \& Mellany, R.J. (2011). Hypovitaminosis D in dogs with inflammatory bowel disease and hypoalbuminaemia. Journal of Small Animal Practice, 52,411-418.

7. Potts J. T. (2005). Parathyroid hormone: pastandpresent . J. Endocrinol, 187(3), 311325.

8. Human, K.L., \& Lane, N.E. (2006). Parathyroid hormone update. Rheum Dis Clin North Am, 32, 703-19.

9. Rubin, M. R. (2002). "The anabolic effects of parathyroid hormone" Osteoporos Int, 13, 267-77.

10. Kimball, S., Fuleihan, G. H., \& Vieth, R. (2008). Vitamin D. A growing perspective. Crit Rev Clin Lab Sci, 45(4), 339-414.

11. Akbel, E. (2005). Yüksek protein içeren diyetle beslenen sıçanlara atkestanesi ekstresi verilmesinin kemik ve kalsiyum metabolizmasına etkileri. (Yayımlanmamış Doktora Tezi) Afyonkarahisar Kocatepe Üniversitesi, Afyonkarahisar, Türkiye.

12. Dawson-Hughes, B., Dallal, G. E., Kral, E.A., Haris, S., Sokol, L. J., \& Falconer, G. (1991). Effect of vitamin D supplementation on winter time and overall bone loss in healthy postmenopausal women. Ann Int Med, 115, 505-12.

13. Tezcan, I. (2012). D Vitamini ve immün sistem. Türkiye Klinikleri, 8(2), 66-8.

14. Bikle, D. (2009). Nonclassic actions of vitamin D. J Clin Endocrinol Metab, 94(1), 2634. 
15. Yang, S., Li, A., Wang, J., Liu, J., Han, Y., Zhamg, W., et al. (2018). Vitamin D receptor: A novel therapeutic target for kidney diseases. Curr Med Chem. 25, 32563271.

16. Fleet, J. C., De Smet, M., Johnson, R., \& Li, Y. (2012). Vitamin D and cancer: A review of molecular mechanisms. Biocherm, 441-6176.

17. Chesney, W.R. (2010). Vitamin D and magic mountain: The anti infectious role of vitamin. J. Pediatr, 156(5), 698-703.

18. Mokhtari, Z., Hekmatdoost, A., \& Nourian, M. (2017). Antioxidant efficacy of vitamin D. Journal of Parathyroid Disease, 5(1), 11-6.

19. Murray, A., Madden, S. F., Synnott, N., Klinger, R., O'Connor, D., O’Donnovan, N., et al. (2017). Vitamin D receptor as a target for breast cancer therapy. Society for Endocrinology, ERC-16-0463.

20. Apperly F.L. (1941). The relation of solar radiation to cancer mortality in North America. Cancer Research, 1, 191-195.

21. Manson, J. E., Mayne, S. T., \& Clinton, S. K. (2011). Vitamin D and prevention of cancer-ready for prime time? (perspective). N. Engl j Med, 364,1385-1387.

22. Deeb, K. K., Trump, D. L., Johnson, C. S. (2007). Vitamin D signaling pathways in cancer: potential for anticancer therapeutics. Nat Rev Cancer, 7, 684 $\square 700$

23. Buras, R. R., Schumaker, L. M., Davoodi, F., Brenner, R. V., Shabahang, M., Nauta, R. J., et al. (1994). Vitamin D receptors in breast cancer cells. Breast Cancer Research and Treatment, 31, 191-202.

24. Brenner, R. V., Shabahang, M., Schumaker, L. M., Nauta, R. J., Uskokovic, M. R., Evans, S. R., et al. (1995). The antiproliferative effect of vitamin D analogs on MCF-7 human breast cancer cells. Cancer Letters, 92, 77-82.

25. Campbell, M. S., Narvaez, C. J., Tenniswood, M., \& Welsh, J. (1996). 1,25Dihidroksivitamin $\mathrm{D}_{3}$ induces morphological and biochemical markers of apoptosis in MCF-7 breast cancer cells. Journal of Steroid Biochemistry and Molecular Bioogy, 58(4), 367-376.

26. Saraçligil, B., Ozturk, B., Unlu, A., Abusoglu, S., \& Tekin, G. (2017). The effect of vitamin D on MCF breast cancer cell metabolism. Bratislava Medical Journal, 118(2), 101-106.

27. Murray, A., Madden, S. F., Synnott, N., Klinger, R., O’Connor, D., O’Donnovan, N., et al. (2017). Vitamin D receptor as a target for breast cancer therapy. Society for Endocrinology, ERC-16-0463.

28. Ar1, M., Karul, A., \& Sakarya, S. (2018). Investigation of antiproliferative, apoptotic and antioxidant effects of oleuropein and vitamin D on breast cancer cell lines (MCF7). MDPI. Proceedings, 2, 1534; doi:10.3390/proceedings 2251534

29. Segovia-Mendoza, M., Diaz, L., Gonzalez-Gonzalez, M. E, Martínez-Reza, I., GarcíaQuiroz, J., Prado-Garcia, H., et al. (2015). Calcitriol and its analogues enhance the antiproliferative activity of gefi-tinib in breast cancer cells. The Journal Steroid Biocheistry and Molecular Biology, 148, 122-131.

30. Rosen, C. J., Adams, J. S., Bikle, D. D., Black, D. M., Demay, M. B., Manson, J. E, et al. (2012). The nonskeletal effects of vitamin D: An endocrine society scientific statement. Endocrine Reviews, 33(3), 456-492.

31. Zgaga, L., Theodoratou, E., Farrington S. M., Din, F. V., Ooi, L. Y., Glodzik, D., et al. (2014). Plasma vitamin D concentration influences survival outcome after a diagnosis of colorectal cancer. Journal of Clinical Oncology, 32 (23), 2430-2439.

32. Spina, C. (2005). Colon cancer and solar ultraviolet B radiation and prevention and treatment of colon cancer in mice with vitamin D and its Gemini analogs. J Steroid Biochem Mol Biol, 97(1-2), 111-120. 
33. Leyssens, C., Marien, E., Verlinden, L., Derua, R., Waelkens, E., Swinnen, J. V., et al. (2015). Remodeling of phospholipid composition in colon cancer cells by $1 \alpha, 25(\mathrm{OH}) 2 \mathrm{D} 3$ and its analogs. The Journal of Steroid Biochemistry and Molecular Biology, 148, 172-178

34. Feldman, D., Krishnan, A. V., Swami, S., Giovannucci, E., \& Feldman, B. J. (2014). The role of vitamin D in reducing cancer risk and progression. Nat Rev Cancer, 14(5), 342-357.

35. Tangpricha, V., Spina, C., Yao, M., Chen T. C., Wolfe, M. M., \& Holick, M. F. (2005). Vitamin D deficiency enhances the growth of MC-26 colon cancer xenograftsin Balb/c mice. J Nutr, 135, 2350-2354.

36. Washington, M. N., \& Weigel, N. L. (2010). 1 $\alpha$-25-dihydroxyvitamin $\mathrm{D}_{3}$ inhibits growth of $\mathrm{VCaP}$ prostate cancer cells despite inducing the growth-promoting TMPRSS2:ERG gene-fusion. Endocrinology, 151, 1409 $\square 1417$.

37. Nair-Shalliker, V., Clements, M., Fenech, M., \& Armstrong, B. K. (2012). Personal sun exposure and serum 25-hydroxy vitamin D concentrations. Photochem Photobiol, 89: 208-14.

38. Feskanich, D., Ma, J., Fuchs, C. S., Kirkner, G. J., Hankinson, S. E., Hollis, B. W., et al. (2004). Plasma vitamin D metabolites and risk of colorectal cancer in women. Cancer Epidemiol Biomarkers Prev, 13, 1502-8.

39. Schwartz, Z., Graham, E. J., Wang, L., Lossdörfer, S., Gay, I., Johnson-Pais, T. L., et al. (2005). Phospholipase A2 activating protein (PLAA) is reuired for 1alpha, 25(OH $)_{2} \mathrm{D}_{3}$ signaling in gowth plate chondrocytes. J Cell Physiol, 203, 54-70.

40. Liu, G., Wilding, G., Staab, M. J. Horvath, D., Miller, K., Dresen, A., et al. (2003). Phase II study of 1alphahydroxyvitamin $\mathrm{D}(2)$ in the treatment of advanced androgenindependent prostate cancer. Clin Cancer Res, 9(11), 4077-83.

41. Wactavski-Wende, J., Kotchen, J. M, Anderson, G. L., Assaf, A. R., Brunner, R. L., O'sullivan, M. J., et al. (2006). Women's health initiative investigators. Calcium plus vitamin D supplementation and the risk of colorectal cancer. N Engl J Med, 354(7), 684-96.

42. Trivedi, D. P, Doll, R., \& Khaw, K. T. (2003). Effect of four-monthly oral vitamin $\mathrm{D}_{3}$ (cholecalciferol) supplementation on fractures and mortality in men and women living in the community: randomised double blind controlled trial. BMJ, 326, 469.

43. Anderson, L. N., Cotterchio M., Vieth R., \& Knight J. A. (2010). Vitamin D and calcium intakes and breast cancer risk in pre-and postmenopausal women. Am J Clin Nutr, 91, 1699-1707.

44. Helzlsouer, K. J, \& VDPP Steering Committee. (2010). Overview of the cohort consortium vitamin D pooling project of rarer cancers. American journal of epidemiology, 172(1), 4-9.

45. Kıdır, M. (2013). D vitamininin immun sistem, deri ve kanser ilişkisi. S.D. Ü Tıp Fak. Derg, 20(4), 158-161.

46. Sintov, A. C., Yarmolinski, L., Dahan, A., \& Ben-Shabat, S. (2014). Pharmacological effects of vitamin D and its analogs: recent developments. Drug Discovery Today, 19(11), 1769-1774.

47. Berkovich, L., Ben-Shabat, S., \& Sintov, A. C. (2010) Induction of apoptosis and inhibition of prostate and breast cancer growth by BGP-15, a new calcipotriene-derived vitamin $\mathrm{D}_{3}$ analog. Anticancer Drugs, 21, 609-618.

48. Hossein-Nezhad, A., \& Holick, M. F. (2013). Vitamin D for health: A global perspective. In: Mayo Clinic Proceedings. 88 (7), 720-55. 
49. Sarı, E., Bülbül, L., Bencer, M., Akçay, T., Özkul Sağlam, T., \& Hatipoğlu, S. (2014). Yüksek doz D vitamini alımı sonucu hiperkalsemi gelişen olguda pamidronat tedavisi. Şişli Etfal Hastanesi Tıp Bülteni, 48(4),322-324.

50. Balkan, F \& Ünal, O. K. (2013). D vitamini intoksikasyonu. Balkan ve Ünal Genel Tip Derg. 23(3), 90-2.

51. Holick, M. F. (2009). Vitamin D Status: Measurement, Interpretation, and Clinical Application. Annals of Epidemiology, 19(2),73-8.

52. Hossein-Nezhad, A., \& Holick, M. F. (2013). Vitamin D for health: A global perspective. In: Mayo Clinic Proceedings, 88 (7); 720-55.

53. Pérez-Barrios, C., Hernández-Álvarez, E., Blanco-Navarro, I., Pérez-Sacristán, B., \& Granado-Lorencio, F. (2016). Prevalence of hypercalcemia related to hypervitaminosis D in clinical practice. Clin Nutr. 35(6): 1354-1358.

54. Aydın, A. E, \& Dokuzlar, E. (2018). Geriatrik bir olguda D vitamini intoksikasyonuna bağlı gelişen akut mental değişiklik. Geriatrik Bilimler Dergisi, 1(2), 73-78.

55. Buluş, D., İnan, Y., Demet, E., \& Andıran, N. (2016). D Vitamini intoksikasyonuna bağlı hiperkalsemi: Olgu Sunumu. Türkiye Çocuk Hastalıkları Dergisi. 4, 277-279.

56. Alikasifoglu, A. (2008). Çocukluk yaş grubunda D vitamini intoksikasyonu. Danone Enstitüsü Beslenme Serileri, 2, 57-61.

57. Mesa, J. M., Sanmartí, A. S., Obiols, G. A., Lucas, A. M., Garciá, F. B., Ribera, E. P., et al. (1983). Vitamin D intoxication in 3 cases of hypothyroidism. Rev Clin Esp, 171(4), 297-299 